\title{
Brain natriuretic peptide (BNP): A diagnostic marker in congestive heart failure-induced acute dyspnea
}

\author{
Sheikh Ishaq ${ }^{\star 1}$, Sheikh Afaq ${ }^{2}$, Harnam Kaur ${ }^{3}$, Neeru Bhaskar ${ }^{4}$, Qazi Najeeb $^{5}$ and Rajesh Pandey \\ Department of Biochemistry, Maharishi Markandeshwar Institute of Medical Science \& Research, Mullana, Ambala, Haryana, India \\ ${ }^{* 1,5}$ Postgraduate, Department of Biochemistry, MMIMSR, Mullana, Haryana, India \\ ${ }^{2}$ Assistant Professor, Department of Internal Medicine, MMIMSR, Mullana, Haryana, India \\ ${ }^{3,6}$ Associate Professor, Department of Biochemistry, MMIMSR, Mullana, Haryana, India \\ ${ }^{4}$ Assistant Professor, Department of Biochemistry, MMIMSR, Mullana, Haryana, India
}

Submission Date: 17-6-2012; Accepted Date: 26-6-2012

\section{INTRODUCTION}

Heart failure (HF) is a clinical syndrome that occurs in patients who because of an inherited or acquired abnormality of cardiac structure and/or function develop a constellation of clinical symptoms (dyspnea and fatigue) and signs (edema and rales) that lead to frequent hospitalizations, a poor quality of life, and a shortened life expectancy. ${ }^{1}$ Acute dyspnea is a common clinical finding with which the patient is admitted in the emergency department. A rapid and accurate investigation of acute dyspnea is vital since treatment of dyspnea can differ markedly depending on the initial clinical impression. However, the rapid and accurate differentiation of heart failure from other causes of dyspnea remains a clinical challenge. After evaluating patient's symptoms, conducting a physical examination, and performing electrocardiography (ECG) and chest radiography, the clinician is often left with considerable diagnostic uncertainty, which results in misdiagnosis and delays the initiation of appropriate therapy. Distinguishing between cardiac and non-cardiac causes of dyspnea is often challenging. Therefore, an assay with high sensitivity and high negative predictive value would be useful both in detecting dyspnea due to heart failure and in ruling out the diagnosis in patients with confounding co-morbid conditions. $^{2}$ A definitive congestive heart failure (CHF) diagnosis is often based on right heart catheterization or indirect

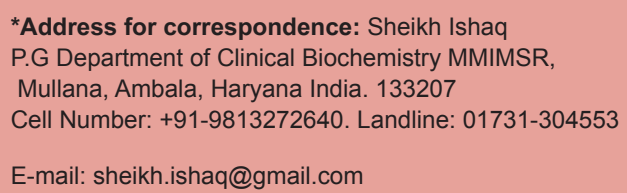

DOI: $10.5530 /$ ijmedph.2.4.4 measurement of ejection fraction by means of radionuclide scanning or echocardiography. Lack of immediate availability and high cost make these studies prohibitive as emergency department screening tests. As a result, an emergency diagnosis of CHF is often based on history and physical examination findings along with results of ancillary tests, such as chest radiography and ECG. ${ }^{3}$ Therefore, a blood test that could rapidly and accurately confirm or exclude the diagnosis of CHF in the urgent care setting would be a valuable clinical tool.

\section{NATRIURETIC PEPTIDES}

Heart is an endocrine organ which secretes natriuretic peptides (Table 1). ${ }^{4,5}$ The natriuretic peptide family consists of atrial natriuretic peptide (ANP), brain natriuretic peptide (BNP), and three other structurally similar peptides: C-type natriuretic peptide (CNP) mostly of central nervous system and endothelial origin, urodilatin from the kidney and dendroaspis natriuretic peptide (DNP), which is of unknown significance. ${ }^{6}$ Since, these peptides are secreted in response to haemodynamic stress, they are promising markers of myocardial dysfunction and heart failure.

The main source of BNP is the ventricles of the heart, although it can also be demonstrated in the atria of the failing heart. BNP is synthesized in bursts and is released predominantly in response to stretching of the ventricular wall and volume overload. The biologic actions of BNP include vasodilatation, diuresis, natriuresis and inhibiting or antagonizing the actions of the renin-angiotensinaldosterone system, the sympathetic nervous system, arginine vasopressin and endothelin. ${ }^{7}$ Elevation of plasma 
Sheikh Ishaq, et al.: Brain natriuretic peptide (BNP): A diagnostic marker in congestive heart failure-induced acute dyspnea

\begin{tabular}{|c|c|c|c|}
\hline Name & Structure & Synthesis & Action \\
\hline Atrial Natriuretic Peptides & 28 amino acid peptide & Myocytes of cardiac atria & $\begin{array}{l}\text { Increase in sodium excretion, } \\
\text { increase glomerular blood } \\
\text { flow, increase in GFR, inhibits } \\
\text { sodium reabsorption, inhibits } \\
\text { aldosterone secretion, decrease } \\
\text { rennin release, lower blood } \\
\text { pressure. }\end{array}$ \\
\hline Urodilatin & 32 amino acid peptide & $\begin{array}{l}\text { Intercalated cells in cortical } \\
\text { collecting duct. }\end{array}$ & Decrease sodium reabsorption. \\
\hline Brain Natriuretic Peptide (BNP) & 32 amino acid peptide. & Myocytes in cardiac ventricle. & Sodium excretion. \\
\hline Guanylin & 15 amino acid peptide. & Goblet cells in colon. & Sodium excretion. \\
\hline Uroguanylin & 16 amino acid peptide. & $\begin{array}{l}\text { Enterochromaffin cell in } \\
\text { duodenum }\end{array}$ & Sodium excretion. \\
\hline C-type natriuretic peptide & 53-amino-acid peptide & $\begin{array}{l}\text { Brain and is found in } \\
\text { high concentrations in } \\
\text { chondrocytes. }\end{array}$ & $\begin{array}{l}\text { CNP is to stimulate long bone } \\
\text { growth. }\end{array}$ \\
\hline
\end{tabular}

$\mathrm{BNP}$ is one of the characteristics of patients with or at risk of diastolic heart failure among subjects with preserved left ventricular systolic function. ${ }^{8}$ Hence, the present study was undertaken to study the levels of BNP and to assess its diagnostic accuracy in CHF.

\section{MATERIALS AND METHODS}

This cross-sectional study was conducted in the Department of Biochemistry in collaboration with the Department of Internal Medicine of Maharishi Markandeshwar Institute of Medical Sciences and Research, Mullana, Ambala (Haryana). 100 patients who were admitted in the ED with complaint of acute dyspnea from May 2011 to April 2012 were included in the study.

INCLUSION CRITERIA: Acute shortness of breath or dyspnea was defined as an abnormally uncomfortable awareness of breathing of less than 7 days duration. Those patients primarily presenting with acute shortness of breath (NYHA class III-IV) constituted the study group.
EXCLUSION CRITERIA: Patients with history of renal disease (serum creatinine $>2.8 \mathrm{mg} / \mathrm{dl}$ ), cirrhosis with ascitis, thyroid dysfunction, trauma chest wall, acute bronchial asthma, pneumonia, acute myocardial infarction, unstable angina and on chronic use of $\beta$-blockers, diuretics and digoxin, angiotensin-converting enzyme inhibitors.

CATEGORIZATION OF PATIENTS: Those patients fulfilling the Framingham's criteria (Table 2) were classified as having dyspnoea due to congestive heart failure (CHF) and those not meeting the criteria, as dyspnea not due to $\mathrm{CHF}$.

SERUM BNP ASSAY: After taking informed and written consent, $10 \mathrm{ml}$ of blood sample was withdrawn from a peripheral vein by a plastic disposable syringe and collected in an air tight lavender top EDTA (ethylenediamino-tetra-acetic acid) plastic tube. The sample was centrifuged and BNP was assayed by chemiluminescence method. ${ }^{10}$

\section{Table 2: Framingham criteria}

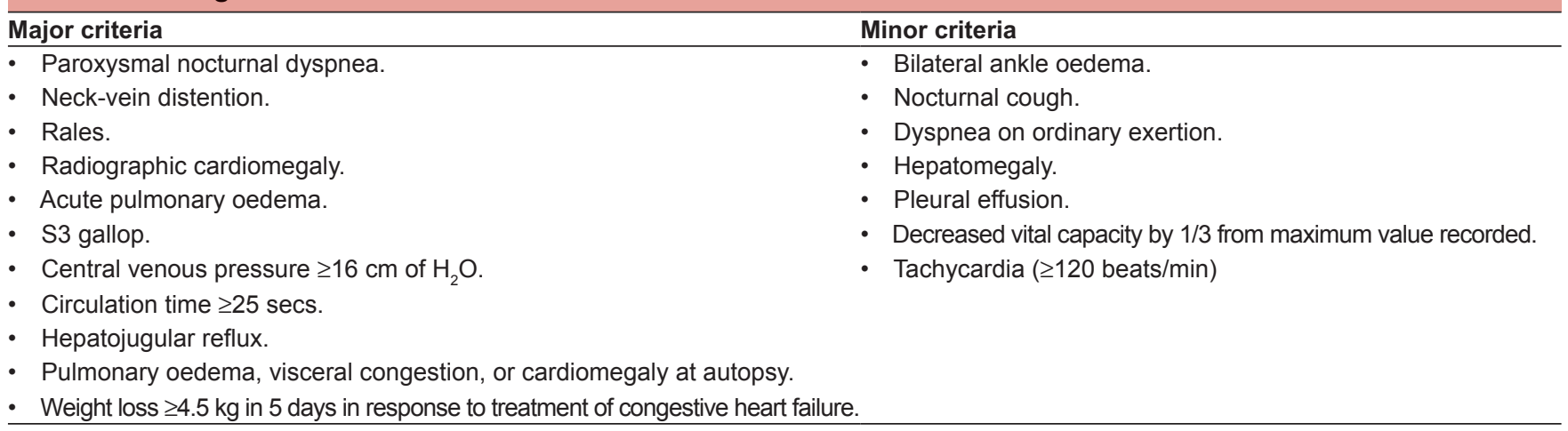


STATISTICAL ANALYSIS: The data obtained was compiled and analyzed using Epi- info version 6.0. Diagnostic accuracy of BNP was evaluated by calculating sensitivity, specificity, positive predictive value and negative predictive value with $95 \%$ confidence intervals.

\section{RESULTS}

The study sample comprised of 100 patients (55 males and 45 females), out of which 60 were diagnosed as having $\mathrm{CHF}$ and 40 as no $\mathrm{CHF}$ where final diagnosis was supported by echocardiography. Serum BNP was more than $100 \mathrm{pg} / \mathrm{ml}$ in 54 patients with CHF and 8 patients without $\mathrm{CHF}$ and it was less than $100 \mathrm{pg} / \mathrm{ml}$ in 6 patients with $\mathrm{CHF}$ and 32 patients without CHF (Table 3 ). Higher mean BNP levels were observed with advancing age particularly in patients with $\mathrm{CHF}$ with highest mean BNP levels of $770.02 \mathrm{pg} / \mathrm{ml}$ in age group of more than 75 years in males and $706 \mathrm{pg} / \mathrm{ml}$ in age group of 66-75 years in females. However, lower BNP levels were observed in patients without CHF with lowest mean BNP levels of $51.05 \mathrm{pg} / \mathrm{ml}$ in age group of $56-65$ years in males, whereas $63.06 \mathrm{pg} / \mathrm{ml}$ in age group of 15-25 years in females (Table 4, Figures 1,2). It was also observed that out of 60 patients diagnosed to have CHF, majority had BNP levels more than $400 \mathrm{pg} / \mathrm{ml}$ (Table 5).

\section{DISCUSSION}

In the present study, 100 patients of different age groups were studied whose predominant symptom was dyspnea of acute onset ( $<7$ days). Out of 100 patients, $55 \%$ were males and $45 \%$ were females. Patients of dyspnea were clinically evaluated which included complete history and examination, ECG and X-ray chest. Subsequently, patients were divided into two groups namely CHF group and No CHF group. Out of 100 patients, 47 were diagnosed to have $\mathrm{CHF}$ and 53 were not having $\mathrm{CHF}$. Cut off of $<100 \mathrm{pg} / \mathrm{ml} \mathrm{BNP}$ levels was taken to exclude heart failure. It was observed that according to BNP levels alone 62 patients had heart failure (BNP levels of $>100 \mathrm{pg} / \mathrm{ml}$ ) and 38 patients had dyspnea not due to heart failure (BNP levels $<100 \mathrm{pg} / \mathrm{ml}$.). In this study, the final diagnosis of $\mathrm{CHF}$ was made in 60 patients and 40 patients were included in No- CHF group (those

\begin{tabular}{|c|c|c|c|c|}
\hline \multirow{2}{*}{$\begin{array}{l}\text { Final diagnosis of CHF based on } \\
\text { echocardiography }\end{array}$} & \multicolumn{2}{|c|}{ Based on serum BNP level } & \multicolumn{2}{|c|}{ Based on clinical evaluation } \\
\hline & $>100 \mathrm{pg} / \mathrm{ml}$ & $<100 \mathrm{pg} / \mathrm{ml}$ & CHF present & CHF absent \\
\hline CHF present & 54 & 06 & 42 & 18 \\
\hline CHF absent & 08 & 32 & 05 & 35 \\
\hline
\end{tabular}

\begin{tabular}{|c|c|c|c|c|c|c|c|}
\hline \multirow[t]{2}{*}{ Age (years) } & \multirow[t]{2}{*}{ Males } & \multirow[t]{2}{*}{ Females } & \multirow[t]{2}{*}{ Total } & \multicolumn{2}{|c|}{$\begin{array}{l}\text { Mean serum BNP in ( } \mathrm{pg} / \mathrm{ml}) \text { in } \\
\text { patients with } \mathrm{CHF}\end{array}$} & \multicolumn{2}{|c|}{$\begin{array}{c}\text { Mean serum BNP }(\mathrm{pg} / \mathrm{ml}) \text { in } \\
\text { patients without CHF }\end{array}$} \\
\hline & & & & Males & Females & Males & Females \\
\hline $15-25$ & 5 & 3 & 8 & 140 & 134 & 57.6 & 63.06 \\
\hline $26-35$ & 4 & 8 & 12 & 243 & 206.5 & 59.2 & 70.58 \\
\hline $36-45$ & 9 & 7 & 16 & 408.4 & 366.5 & 53.06 & 125.6 \\
\hline $46-55$ & 10 & 8 & 18 & 550.17 & 343 & 200 & 109.12 \\
\hline $56-65$ & 8 & 7 & 15 & 404.35 & 480.75 & 51.05 & 102 \\
\hline $66-75$ & 6 & 6 & 12 & 394.32 & 706 & 63.9 & 65.2 \\
\hline$>75$ & 13 & 6 & 19 & 770.02 & 628 & 78 & 84 \\
\hline Total & 55 & 45 & 100 & & & & \\
\hline
\end{tabular}

\begin{tabular}{lccc}
\hline Table 5: Serum BNP levels in patients with or without final diagnosis of CHF & \\
\hline BNP levels (in pg/ml) & With CHF & No CHF & Total \\
\hline$<100$ & 6 & 32 & 38 \\
$100-199$ & 1 & 3 & 4 \\
$200-299$ & 5 & 3 & 8 \\
$300-399$ & 10 & 1 & 11 \\
$400-699$ & 20 & 0 & 20 \\
$>700$ & 18 & 1 & 19 \\
Total & 60 & 40 & 100 \\
\hline
\end{tabular}


Table 6: Diagnostic accuracy of serum BNP levels versus clinical evaluation

\begin{tabular}{lcc}
\hline Diagnostic accuracy & Serum BNP levels (pg/ml) & Clinical assessment \\
\hline Sensitivity & $90 \%(78.83-95.86)$ & $70(56.62-80.79)$ \\
Specificity & $80 \%(63.86-90.38)$ & $87.5(72.39-95.30)$ \\
Positive predictive value & $87.09 \%(75.59-93.38)$ & $89.36(76.10-96.01)$ \\
Negative predictive value & $84.21 \%(68.07-93.41)$ & $66.03(51.64-78.11)$ \\
\hline
\end{tabular}

patients who had non cardiac dyspnea). It was observed that clinical examination has a sensitivity of $70 \%$, specificity of $87.5 \%$, positive predictive value of $89.36 \%$, negative predictive value of $66.03 \%$ for diagnosing CHF where as BNP levels has a sensitivity of $90 \%$, specificity of $80 \%$, positive predictive value of 87.09 , negative predictive value of 84.21 for diagnosing CHF (Table 6). It was also observed that out of 100 patients 9 patients which included 7 males and 2 females had normal systolic functions (LVEF $>50 \%$ ) but were included in the final diagnosis of diastolic heart failure by the cardiologist based on diastolic filling abnormalities on echocardiography. All these 9 patients had BNP levels $>100 \mathrm{pg} / \mathrm{ml}$ (mean BNP $523.9 \mathrm{pg} / \mathrm{ml}$ ). Out of these 9 patients, 3 patients had initial clinical diagnosis of heart failure. Similarly, in a study conducted by Lubien $\mathrm{E}$ et $\mathrm{al}^{11}$ it was found that BNP can reliably detect diastolic heart failure in presence of normal left ventricular systolic function. Therefore, BNP assay can reinforce the diagnosis of diastolic heart failure in such patients. Furthermore, it was seen that 18 patients had BNP levels of more than $700 \mathrm{pg} / \mathrm{ml}$ at the time of admission. These patients had severe heart failure and majority had markedly reduced ejection fraction. Out of these, 8 died within 7 days of hospital stay which indicates the correlation of BNP levels with severity of CHF and also its prognostic significance. Martin and Ricou ${ }^{12}$ also reported that raised $\mathrm{BNP}$ has a prognostic value to predict mortality after CHF.

\section{CONCLUSION}

There is strong and convincing evidence that BNP is a reliable and useful biomarker in acute dyspnea due to $\mathrm{CHF}$ and has a diagnostic as well as prognostic value. Used in conjunction with other clinical information, rapid measurement of BNP may reduce the total treatment cost of patients. Due to its prognostic implication it is recommended that BNP should be measured in all the patients with clinical signs of CHF even if the diagnosis is apparent. A careful history and examination of the patient and a systematic search for complicating factors is necessary for the appropriate analysis and the correct use of these biomarkers.

\section{DISCLOSURE OF POTENTIAL CONFLICTS OF INTEREST}

The authors indicate no potential conflicts of interest.

\section{ETHICAL CONSIDERATION}

The protocol for this study was approved by the Institutional Ethical Committee. All work was performed according to the international guidelines for human experimentation and biomedical research. ${ }^{13}$ Approval was obtained from the subjects by taking the informed consent.

\section{REFERENCES}

1. Douglas L, Murali C. Heart failure and cor pulmonale. In, Longo, Fauci, Kasper, Hauser, Jameson, Sloscalzo et al editors. Harrison's Principles of Internal Medicine $18^{\text {th }}$ edition. New York, McGraw-Hill.2012; Chapter 234, pages no 1901 vol 2.

2. Prahash A, lynch T. B-type natriuretic peptide: a diagnostic, prognostic, and therapeutic tool in heart failure. American journal of critical care. 2004; 13: 46-55.

3. Collins SP, Lindsell CJ, Peacock WF, Hedger VD, Askew J, Eckert DC, Storrow AB. The combined utility of an S3 heart sound and B-type natriuretic peptide levels in emergency department patients with dyspnea. J Card Fail, 2006; 12(4):286-92.

4. Metabolism of water and electrolytes, In textbook of biochemistry, second edition, Lal H, Pandey R, CBS Publishers and distributors Pvt. Ltd. New Delhi 2011; chapter 26, 436-7.

5. Lincoln R. Potter, Sarah Abbey-Hosch and Deborah M. Dickey. Natriuretic Peptides, Their Receptors, and Cyclic Guanosine MonophosphateDependent Signaling Functions. Endocrine Reviews, 2006; 27(1):47-72 53.

6. Levin ER, Gardner DG, Samson WK. Natriuretic peptide. N Engl J Med, 1998; 339: 321-8.

7. Moe GW. B-type natriuretic peptide in heart failure. Current opinion in cardiology Indian edition 1 2006; 224-30.

8. Hitoshi $Y$, Junichi $Y$, Kazuhiro $Y$, Yasushi S, Toshiaki M, Noriyuki A, Masatsugu $\mathrm{H}$, Young $\mathrm{JL}$, Masayoshi $\mathrm{M}$ and Tohru M. Elevation of plasma brain natriuretic peptide is a hallmark of diastolic heart failure independent of ventricular hypertrophy. J Am Coll Cardiol 2004; 43:55-60.

9. Ho KL, Prinsky JL, Kannel WB, Levy D. The epidemiology of heart failure; The Framingham Study. 1993; J Am Coll Cardiol 22 (Suppl A): 6A.

10. ADVIA Centaur Assay Manual -BNP, 131073, rev 2003-02, Bayer Healthcare, Diagnostics Division, Tarrytown NY.

11. Lubien E, DeMaria, Krishnaswamy P, Clopton P, Koon J, Kazanegra R, Gardetto N, Wanner E, Maisel AS. Utility of B-Natriuretic Peptide in detecting diastolic dysfunction. Comparison with Doppler velocity recordings. Circulation 2002; 105:595.

12. Martin-Du Pan RC, Ricou F. Use of brain natriuretic peptide (BNP) in the diagnosis and treatment of heart failure. Rev Med Suisse Romande. 2003; 123(2):125-8.

13. World Medical Association declaration of Helsinki. Ethical Principles for Medical Research involving Human subjects. World Medical Association available from; http://www.wma.net/e/policy/b3html. 